\title{
PENINGKATAN KEMURNIAN DAN TOKSISITAS EKSTRAK PIGMEN C-FIKOSIANIN DARI SIANOBAKTERIA LAUT Jaaginema sp. BTM-11 DENGAN MENGGUNAKAN KITOSAN DAN ARANG AKTIF
}

\section{Enhancement of Purity and Toxicity of C-Phycocyanin Pigment Extracted from Marine Cyanobacteria Jaaginema sp. BTM-11 Using Chitosan and Activated Carbon}

\author{
Swastika Praharyawan ${ }^{1 *}$, Tri Setyaningsih ${ }^{2}$, Dwi Susilaningsih ${ }^{1}$, dan \\ Yusraini Dian Inayati Siregar² \\ ${ }_{1}^{1}$ Pusat Penelitian Bioteknologi, Lembaga IImu Pengetahuan Indonesia, Jl. Raya Bogor KM. 46, Cibinong, Bogor, Indonesia \\ ${ }^{2}$ Program Studi Kimia, Fakultas Sains dan Teknologi, Universitas Islam (UIN) Syarif Hidayatullah Jakarta \\ JI. Ir. H. Juanda No. 95, Ciputat, Indonesia \\ *Korespondensi Penulis: swastika.praharyawan@gmail.com
}

Diterima: 23 November 2018; Direvisi: 15 Maret 2019; Disetujui: 17 Mei 2019

\begin{abstract}
ABSTRAK
C-fikosianin adalah senyawa pigmen-aksesori fotosintetik berwarna biru yang terkandung dalam sianobakteria. Jaaginema sp. BTM-11 merupakan sianobakteria laut yang memiliki potensi sebagai penghasil pigmen $\mathrm{C}$-fikosianin karena kandungannya yang tinggi. Nilai ekonomis pigmen C-fikosianin sangat ditentukan oleh rasio kemurnian yang dimilikinya. Penelitian ini bertujuan untuk meningkatkan kemurnian pigmen C-fikosianin dari ekstrak sianobakteria laut Jaaginema sp. BTM-11 dengan menggunakan kitosan dan arang aktif. Variabel independen pada penelitian ini adalah konsentrasi kitosan (0,075-3,750 g/L) dan konsentrasi arang aktif (2,5-10 g/L). Toksisitas C-fikosianin diuji dengan menggunakan metode Brine Shrimp Lethality Test (BSLT) untuk mendapatkan nilai Konsentrasi Letal-50 $\left(\mathrm{LC}_{50}\right)$. Penggunaan kitosan konsentrasi $0,3 \mathrm{~g} / \mathrm{L}$ yang dilanjutkan dengan penggunaan arang aktif konsentrasi $5,0 \mathrm{~g} / \mathrm{L}$ berhasil meningkatkan rasio kemurnian pigmen C-fikosianin sebesar 57,5 dan $167,5 \%$, secara berturut-turut. Kapasitas pengikatan kitosan dan kapasitas penjerapan arang aktif secara signifikan berhasil meningkatkan

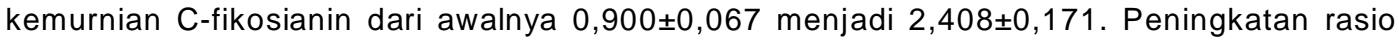
kemurnian C-fikosianin juga diikuti dengan peningkatan toksisitas fraksi C-fikosianin sianobakteria laut Jaaginema sp. BTM-11. Nilai LC $_{50}$ ekstrak Jaaginema sp. BTM-11 sebelum pemurnian yang sebesar 15,75 ppm meningkat menjadi 12,06 ppm setelah dimurnikan dengan kitosan dan arang aktif.
\end{abstract}

KATA KUNCI : C-fikosianin, sianobakteria laut, Jaaginema sp. BTM-11, kitosan, arang aktif

\section{ABSTRACT}

C-phycocyanin is a blue colored accessory photosynthetic pigment found in cyanobacteria. Jaaginema sp. BTM-11 is marine cyanobacteria which is potential to be used as C-phycocyanin producer due to its high contents. The economical value of the blue pigment, C-phycocyanin, is determined by its purity. This research aimed to enhancing the purity of C-phycocyanin extracted from marine cyanobacteria of Jaaginema sp. BTM-11 using chitosan and activated carbon. The independent variables of this research were chitosan concentration $(0.075-3.750 \mathrm{~g} / \mathrm{L})$ and activated carbon concentration (2.50-10.0 g/L). The toxicity test of C-phycocyanin was carried out using Brine Shrimp Lethality Test (BSLT) method to obtain the Lethal Concentration-50 (LC $\left.{ }_{50}\right)$ value. The application of $0.3 \mathrm{~g} / \mathrm{L}$ chitosan continued by of $5.0 \mathrm{~g} / \mathrm{L}$ activated carbon was successfully increased the purity of C-phycocyanin by 57.5 and $167.5 \%$, respectively. Binding capacity of chitosan and adsorption capacity of activated carbon succeed to significantly increase the purity ratio of $C$ phycocyanin from $0.900 \pm 0.067$ to $2.408 \pm 0.171$. The enhancement of purity ratio of $C$-phycocyanin fraction extracted from Jaaginema sp. BTM-11 was also followed by the enhancement of its toxicity. $L C_{50}$ of C-phycocyanin extract before purification $(15.75 \mathrm{ppm})$ was lower compared to the $C$ phycocyanin fraction (12.06 ppm) after being treated with chitosan and activated carbon.

KEYWORDS : C-phycocyanin, marine cyanobacteria, Jaaginema sp. BTM-11, chitosan, activated carbon

Copyright @ (c) 2019, JPBKP, Nomor Akreditasi : 30/E/KPT/2018

DOI : http://dx.doi.org/10.15578/jpbkp.v14i1.569 


\section{PENDAHULUAN}

Sianobakteria merupakan mikroorganisme prokariot fotoautotropik yang sangat beragam dan kaya akan kandungan pigmen serta biometabolit lain yang memiliki fungsi spesifik (Rastogi \& Sinha, 2009; Sinha, 1996). Sianobakteria mengandung fikobiliprotein dalam jumlah yang tinggi yang terasosiasi dengan kompleks-pemanen-cahaya di dalam fotosistem yang disebut dengan fikobilisom. Fikobilisom terdiri atas inti dan batang yang saling bergabung dan mengandung allofikosianin sebagai inti yang dikelilingi oleh C-fikosianin dan terkadang juga oleh C-fikoeritrin yang terdapat dalam batang fikobilisom (Maccoll, 1998). C-fikosianin adalah pigmen fotosintesis aksesori berwarna biru yang menyerap cahaya pada kisaran panjang gelombang $620 \mathrm{~nm}$ dan memancarkan sinar fluoresensi pada panjang gelombang 640 nm (Gantar, Simovic, Djilas, Gonzalez, \& Miksovska, 2012).

Tidak seperti allofikosianin dan C-fikoeritrin, C-fikosianin merupakan pigmen aksesori utama yang terdapat pada semua sianobakteria (Gantar et al., 2012). Secara tradisional, pigmen C-fikosianin diisolasi dari Spirulina (Bhaskar, Gopalaswamy, \& Raghu, 2005), namun begitu tidak menutup kemungkinan untuk memproduksi pigmen tersebut dari jenis sianobakteria lain (Santiago-santos, Ponce-noyola, Olvera-ram, Ortega-lópez, \& Cañizares-villanueva, 2004). Oleh karena itu, eksplorasi sianobakteria potensial penghasil pigmen $\mathrm{C}$-fikosianin dari spesies lain perlu dilakukan. Beberapa spesies sianobakteria memiliki kandungan pigmen C-fikosianin yang lebih tinggi (per berat kering) dibandingkan dengan Spirulina, salah satunya adalah galur sianobaketria laut lokal, yaitu Jaaginema sp. BTM-11.

Pigmen C-fikosianin memiliki potensi untuk aplikasi yang luas, seperti sebagai pewarna makanan, pewarna kosmetika, atau sebagai bahan aktif biologis (Fernández-rojas, Hernández-juárez, \& Pedrazachaverri, 2014; Martelli, Folli, Visai, Daglia, \& Ferrari, 2014). Aplikasi pigmen $C$-fikosianin tersebut sangat ditentukan oleh tingkat kemurnian dari C-fikosianin yang digunakan. Peningkatan kemurnian $\mathrm{C}$-fikosianin akan meningkatkan nilai ekonomisnya serta aktivitas biologisnya, sehingga aplikasinya menjadi lebih bersifat spesifik (Cisneros \& Rito-palomares, 2014). Berbagai teknik pemurnian C-fikosianin telah dikembangkan, salah satu teknik yang umum digunakan adalah kromatografi penukar ion (Silveira, Quines, Burkert, \& Kalil, 2008). Namun, teknik tersebut memiliki kelemahan, yaitu waktu yang lama dan kuantitas C-fikosianin yang bisa dimurnikan hanya sedikit. Di sisi lain, teknik pemurnian C-fikosianin yang lebih praktis telah dikembangkan, yaitu dengan menggunakan kitosan dan arang aktif (Gantar et al., 2012).

Gupta \& Sainis (2010) berhasil meningkatkan rasio kemurnian C-fikosianin yang diekstrak dari Synechococcus sp. lebih dari 100\% dengan menggunakan kitosan dan arang aktif. Hasil yang sama juga ditunjukkan oleh Fekrat, Nami, Ghanavati, Ghaffari, \& Shahbazi (2018) yang berhasil memanfaatkan kitosan dan arang aktif untuk meningkatkan rasio kemurnian pigmen $\mathrm{C}$-fikosianin sebesar $67 \%$ yang diekstrak dari Arthrospira platensis. Di sisi lain, sianobakteria lokal yang diketahui memiliki kandungan pigmen C-fikosianin tinggi belum banyak mendapat perhatian. Mengingat kemanfaatan pigmen C-fikosianin yang luas serta tingginya potensi kandungan pigmen C-fikosianin yang dimiliki oleh sianobakteria lokal, maka penelitian terkait produksi C-fikosianin oleh sianobakteria lokal perlu dilakukan. Oleh karena itu, studi ini bertujuan untuk memurnikan C-fikosianin yang diproduksi oleh sianobakteria laut, Jaaginema sp. BTM11, dengan menggunakan kitosan dan arang aktif, serta mengukur perubahan toksisitasnya dalam rangka aplikasinya sebagai senyawa aktif biologis.

\section{BAHAN DAN METODE}

\section{Sianobakteria dan Kondisi Kultivasi}

Galur sianobakteria yang digunakan dalam penelitian ini (Gambar 1) diisolasi dari perairan laut di Pulau Batam, Kepulauan Riau, Indonesia. Galur tersebut merupakan bagian dari koleksi mikroalga dan sianobakteria yang dimiliki oleh Laboratorium Bioenergi dan Bioproses, Pusat Penelitian Bioteknologi-LIPI. Hasil identifikasi yang dilakukan, baik secara morfologi maupun molekuler (Mustopa, Nurilmala, \& Susilaningsih, 2016), menunjukkan bahwa galur sianobakteria tersebut adalah Jaaginema sp. BTM11. Kultur Jaaginema sp. BTM11 ditumbuhkan dalam media yang secara khusus dirancang untuk galur sianobakteria tersebut yaitu mengandung (mM) $3,1 \mathrm{NaNO}_{3} ; 0,014 \mathrm{Na}_{2} \mathrm{HPO}_{4} ; 0,037 \mathrm{KH}_{2} \mathrm{PO}_{4} ; 0,011$ $\mathrm{C}_{6} \mathrm{H}_{5} \mathrm{FeO}_{7} ; 0,034 \mathrm{CaCl}_{2} \cdot 2 \mathrm{H}_{2} \mathrm{O} ; 0,004 \mathrm{Na}_{2}$ EDTA. $2 \mathrm{H}_{2} \mathrm{O}$ dan $0,28 \mathrm{C}_{6} \mathrm{H}_{8} \mathrm{O}_{7}$.

Kultur sianobakteria ditumbuhkan di dalam botol berukuran $600 \mathrm{~mL}$ dengan $500 \mathrm{~mL}$ media selama 7 hari (Praharyawan, Rahman, \& Susilaningsih, 2016). Kultur diaerasi secara berkesinambungan dengan menggunakan aerator dan diberi penyinaran di bawah lampu neon 18 watt dengan intensitas cahaya 2500 lux pada suhu kamar. Pertumbuhan sianobakteria di dalam kultur dipantau melalui pengukuran absorbansi 


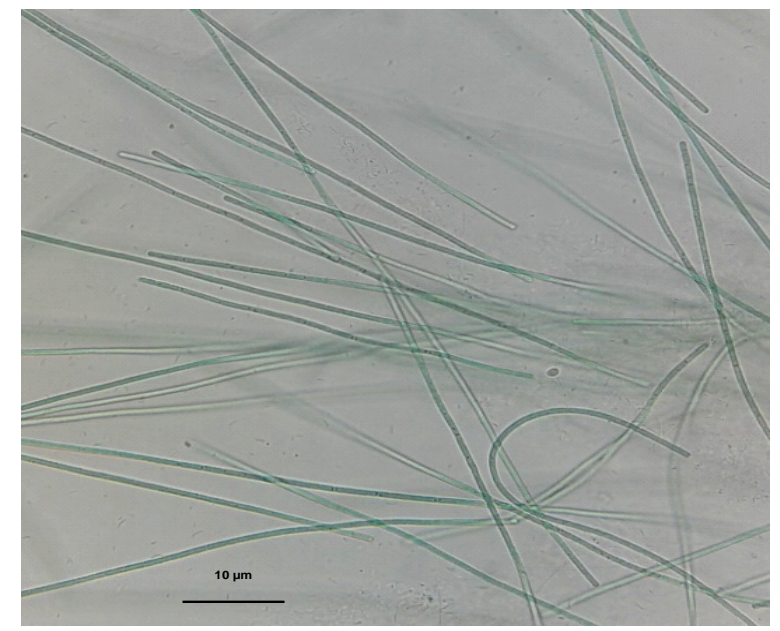

Gambar 1. Penampakan mikroskopis Jaaginema sp. BTM-11 pada perbesaran 400x

Figure 1. Microscopic photograph of Jaaginema sp. BTM-11, examined at 400x magnification

pada panjang gelombang $680 \mathrm{~nm}$ menggunakan Spektrofotometer UV-Vis (Shimadzu Pharmaspec UV 1700).

\section{Ekstraksi dan Analisa Fikosianin}

Metode freeze-thawing digunakan untuk mengekstrak fikosianin dari biomassa Jaaginema sp. BTM11 (Horvath, Attila, Riddick, \& Presing, 2013). Secara singkat, $20 \mathrm{~mL}$ buffer fosfat $0,1 \mathrm{M} \mathrm{pH} 7$ ditambahkan ke dalam tabung yang berisi biomassa basah sianobakteria Jaaginema sp. BTM-11 yang sebelumnya dikumpulkan dengan cara disentrifugasi. Campuran larutan Ialu disimpan pada suhu $4{ }^{\circ} \mathrm{C}$ selama kurang lebih 6 jam hingga membeku, kemudian didiamkan pada suhu kamar di ruang gelap hingga mencair. Langkah tersebut terus dilakukan hingga terlihat warna biru pada campuran larutan sianobakteria. Larutan ekstrak kasar fikosianin dipisahkan dari residu biomassa dengan menggunakan sentrifuse pada kecepatan $6000 \mathrm{rpm}$ selama 10 menit. Ekstraksi dengan metode freezethawing terus dilakukan hingga supernatan tidak berwarna biru lagi (Ilter et al., 2018).

Kandungan fikosianin dianalisa dengan menggunakan Spektrofotometer Visibel pada panjang gelombang 565, 620 dan $650 \mathrm{~nm}$. Kandungan fikosianin dalam supernatan hasil ekstraksi atau ekstrak kasar dihitung dengan menggunakan formula sebagai berikut (Becker, 1994):

Kadar pigmen fikosianin $(\mathrm{mg} / \mathrm{mL})=\frac{A_{620}-\left(0,7 \times A_{650}\right)}{7.38}$

Keterangan:

$A_{620}$ : Absorbansi pada panjang gelombang $620 \mathrm{~nm}$ $A_{650}$ : Absorbansi pada panjang gelombang $650 \mathrm{~nm}$

\section{Pemurnian Fikosianin}

Pada penelitian ini, fikosianin dimurnikan dengan menggunakan kitosan dan arang aktif (Fekrat et al., 2018; Gupta \& Sainis, 2010). Setiap proses pemurnian dilakukan dalam tiga kali ulangan. Proses pemurnian diawali dengan penambahan kitosan (Sigma-Aldrich ${ }^{\circledR}$ ) ke dalam ekstrak kasar fikosianin, lalu campuran larutan dihomogenkan dengan menggunakan pengaduk magnetik selama 2 menit. Setelah itu, larutan disentrifugasi selama 10 menit dengan kecepatan $6000 \mathrm{rpm}$. Supernatan diambil, lalu arang aktif $\left(\right.$ Merck $\left.^{\circledR}\right)$ ditambahkan ke dalam supernatan untuk selanjutnya dihomogenkan menggunakan pengaduk magnetik selama 5 menit. Campuran larutan Ialu disentrifugasi pada kecepatan 6000 rpm selama 10 menit, supernatan lalu diambil. Proses pemurnian dilanjutkan dengan metode presipitasi menggunakan ammonium sulfat $50 \%$ (Fekrat et al., 2018). Presipitasi dilakukan selama kurang lebih 24 jam pada suhu $4^{\circ} \mathrm{C}$. Larutan selanjutnya disentrifugasi pada kecepatan 6000 rpm selama 10 menit, endapan fikosianin berwarna biru diambil. Endapan fikosianin selanjutnya dilarutkan dalam buffer fosfat $0,1 \mathrm{M} \mathrm{pH} 7,0$. Kemurnian fikosianin diukur dengan menggunakan metode Spektrofotometri UV-Vis pada panjang gelombang 280 dan $620 \mathrm{~nm}$. Formula untuk menghitung rasio kemurnian (RK) fikosianin adalah sebagai berikut (Gantar et al., 2012):

$$
\mathrm{RK}=\frac{A_{620}}{A_{280}}
$$

Keterangan:

RK : Rasio kemurnian

$\mathrm{A}_{280}$ : Absorbansi pada panjang gelombang $280 \mathrm{~nm}$

$\mathrm{A}_{620}$ : Absorbansi pada panjang gelombang $620 \mathrm{~nm}$ 


\section{Uji Toksisitas Brine Shrimp Lethality Test/BSLT}

Metode BSLT digunakan dalam menguji tingkat toksisitas pigmen fikosianin sebelum dan setelah proses pemurnian dilakukan. Pengujian BSLT mengikuti metode yang dikembangkan oleh Meyer et al. (1982). Larutan $\mathrm{NaCl} 25 \%$ digunakan sebagai larutan kontrol dan sebagai pelarut dalam setiap larutan uji C-fikosianin yang digunakan dalam uji toksisitas BSLT. Larutan uji C-fikosianin divariasikan menjadi tiga konsentrasi, yaitu 10, 100 dan 1000 ppm. Tiga pengulangan dilakukan untuk masing-masing konsentrasi pada uji ini. Larutan yang mengandung senyawa uji (fikosianin) dan larva Artemia salina dihomogenkan secara perlahan di dalam vial. Larutan kontrol juga dipersiapkan sebagai pembanding. Larutan uji dan kontrol dibiarkan selama 24 jam di bawah cahaya lampu neon 18 watt. Setelah 24 jam, larva Artemia yang mati (mortalitas) di masing-masing vial uji dan kontrol dihitung. Tingkat toksisitas dibandingkan antara sampel fikosianin sebelum dan sesudah proses pemurnian.

\section{Analisa Statistika}

Semua perlakuan dalam eksperimen pemurnian dengan menggunakan kitosan dan arang aktif dilakukan dalam tiga kali ulangan. Analisa statistika uji-t (taraf signifikan $=0,05$ ) dilakukan menggunakan peranti lunak Microsoft Excel 2016 (Data Analysis ToolPak) dilakukan pada eksperimen pemurnian Cfikosianin. Untuk uji toksisitas, data mortalitas Artemia yang diolah menggunakan metode analisa probit dengan bantuan peranti lunak Microsoft Excel 2016 dilakukan untuk memperoleh nilai $\mathrm{LC}_{50}$

\section{HASIL DAN PEMBAHASAN}

Jaaginema sp. BTM-11 merupakan filamentus sianobakteria di mana selnya berbentuk silindrikal. Kultivasi sianobakteria Jaaginema sp. BTM-11 dilakukan hingga pertumbuhannya mencapai tahap akhir fase logaritmik, yaitu pada hari ke-7. Jumlah sel sianobakteria yang maksimal pada hari ke-7 diharapkan mampu untuk menyediakan metabolit yang diinginkan dalam jumlah yang maksimal untuk diekstraksi. Media khusus yang digunakan dalam kultivasi Jaaginema sp. BTM-11 mampu menyediakan nitrat (sumber nitrogen), sebagai komponen utama, dan mineral lainnya dalam jumlah yang sesuai, sehingga pertumbuhan sianobakteria tersebut dapat berlangsung dengan baik. Pertumbuhan yang baik ditandai dengan tersuspensinya filamen-filamen Jaaginema sp. BTM-11 secara merata di dalam media, sedangkan pertumbuhan yang tidak baik ditandai dengan terkolonisasinya filamen-filamen Jaaginema sp. BTM-11, sehingga sel-sel sianobakteria di dalam kultur akan mengendap dan pertumbuhan tidak berjalan maksimal.

Sianobakteria Jaaginema sp. BTM-11 memiliki potensi sebagai penghasil pigmen biru, C-fikosianin, karena kandungannya di dalam sel cukup tinggi, yaitu bisa mencapai lebih dari 40\% (per berat kering biomassa). Secara ekonomi, pigmen C-fikosianin yang termasuk ke dalam golongan fikobiliprotein memiliki nilai yang tinggi mengingat harganya yang mahal, yaitu US $\$ 5.000$ - $\$ 33.000$ per gram (Sekar \& Chandramohan, 2008). Nilai ekonomi pigmen fikobiliprotein ditentukan oleh tingkat kemurniannya, semakin tinggi tingkat kemurniannya, maka akan semakin tinggi pula harganya. Oleh karena itu, usaha untuk mendapatkan pigmen C-fikosianin dengan kemurnian yang tinggi perlu dilakukan.

Kitosan dan arang aktif telah terbukti mampu untuk meningkatkan secara signifikan tingkat kemurnian pigmen C-fikosianin yang diekstrak dari sianobakteria (Gantar et al., 2012; Patil, Chethana, Sridevi, \& Raghavarao, 2006). Kitosan dan arang aktif masingmasing memiliki peran yang berbeda dalam proses pemurnian C-fikosianin yang diharapkan dapat bersinergi meningkatkan derajat kemurnian pigmen C-fikosianin.

Pada Tabel 1 terlihat bahwa penambahan kitosan pada konsetrasi yang paling kecil $(0,075 \mathrm{~g} / \mathrm{L})$ secara

Tabel 1. Pengaruh kitosan pada pemurnian pigmen C-fikosianin

Table 1. The effect of chitosan in the purity of C-phycocyanin pigment

\begin{tabular}{lcc}
\hline \multicolumn{1}{c}{$\begin{array}{c}\text { Perlakuan/ } \\
\text { Treatment }\end{array}$} & $\begin{array}{c}\text { Rasio Kemurnian/ } \\
\text { Purity Ratio } \\
\left(\mathbf{A}_{\mathbf{6 2 0}} / \mathbf{A}_{\mathbf{2 8 0}}\right)\end{array}$ & $\begin{array}{c}\text { Persentase Peningkatan/ } \\
\text { Increasing Percentage } \\
\text { (\%) }\end{array}$ \\
\hline Ekstrak kasar/Crude Extract & $0.90 \pm 0.07$ & 0.0 \\
Kitosan/Chitosan $0.075 \mathrm{~g} / \mathrm{L}$ & $1.35 \pm 0.07$ & 49.4 \\
Kitosan/Chitosan $0.150 \mathrm{~g} / \mathrm{L}$ & $1.32 \pm 0.04$ & 46.2 \\
Kitosan/Chitosan $0.225 \mathrm{~g} / \mathrm{L}$ & $1.36 \pm 0.04$ & 50.6 \\
Kitosan/Chitosan $0.300 \mathrm{~g} / \mathrm{L}$ & $1.42 \pm 0.04$ & 57.5 \\
Kitosan/Chitosan $0.375 \mathrm{~g} / \mathrm{L}$ & $1.41 \pm 0.01$ & 56.4 \\
\hline
\end{tabular}


signifikan (uji-t) dapat meningkatkan derajat kemurnian pigmen C-fikosianin pada ekstrak Jaaginema sp. BTM-11 jika dibandingkan dengan ekstrak awalnya. Hasil tersebut menunjukkan bahwa penggunaan kitosan dengan konsentrasi 0,075 g/L sudah cukup baik dalam memurnikan C-fikosianin dari ekstrak kasar sianobakteria laut Jaagniema sp BTM-11. Secara ekonomi, penggunaan kitosan dengan konsentrasi yang lebih rendah tentu akan sangat menguntungkan bagi proses pemurnian skala besar. Dari hasil yang didapat terlihat bahwa kitosan memiliki kapasitas pengikatan yang kuat terhadap sel-sel debris sianobakteria dan komponen lainnya yang terdapat dalam ekstrak kasar C-fikosianin. Hal tersebut disebabkan oleh adanya gugus amino dan hidroksil pada struktur molekul kitosan (Patil et al., 2006). Kemampuan mengikat kitosan terhadap berbagai senyawa kimia, termasuk mineral dan senyawa polianion, telah diketahui secara luas dan mendalam, sehingga penggunaannya dalam proses pemurnian C-fikosianin dinilai sangat tepat (Vold, Varum, Guibal, \& Smidsrød, 2003). Dari Tabel 1 dapat dilihat bahwa persentase terbesar peningkatan rasio kemurnian C-fikosianin (57,5\%) diperoleh dari penambahan kitosan sebanyak 0,3 g/L. Hal itu mengindikasikan bahwa 0,3 g/L adalah jumlah kitosan yang harus ditambahkan ke dalam larutan pigmen Cfikosianin untuk mendapatkan peningkatan rasio kemurnian yang optimum. Oleh karena itu, sampel C-fikosianin yang telah dimurnikan dengan perlakuan penambahan kitosan 0,3 $\mathrm{g} / \mathrm{L}$ dipilih untuk proses pemurnian selanjutnya dengan menggunakan arang aktif. Rasio kemurnian C-fikosianin yang diperoleh dengan penambahan kitosan 0,3 $\mathrm{g} / \mathrm{L}$ berbeda secara signifikan (uji-t) dengan rasio kemurnian awal ekstrak Jaaginema sp. BTM-11.

Tabel 2 menunjukkan hasil pemurnian dengan menggunakan arang aktif. Pada tahap ini, arang aktif berperan sebagai adsorber bagi protein-protein pengotor dan senyawa lainnya yang masih terkandung dalam ekstrak pigmen C-fikosianin (Patil et al., 2006).
Peningkatan kemurnian C-fikosianin yang didapat sangat signifikan bila dibandingkan dengan kemurnian awal sebelum mendapat perlakuan. Penggunaan arang aktif dengan konsentrasi $5 \mathrm{~g} / \mathrm{L}$ memberikan hasil peningkatan rasio kemurnian paling besar, yaitu sebesar $167,5 \%$, dan berbeda secara signifikan dengan rasio kemurnian sebelumnya, yaitu kemurnian yang didapatkan dari perlakuan kitosan 0,3 g/L. Meskipun demikian, hasil rasio kemurnian yang didapat antara perlakuan arang aktif konsentrasi 2,5 $\mathrm{g} / \mathrm{L}$ dengan konsentrasi $5,0 \mathrm{~g} / \mathrm{L}$ tidak menunjukkan perbedaan yang signifikan. Oleh karena itu, melihat hasil tersebut maka penggunaan arang aktif sebesar 2,5 g/L sudah cukup baik untuk memurnikan Cfikosianin dari ekstrak Jaaginema sp. BTM-11. Kapasitas arang aktif dalam menjerap berbagai senyawa telah terbukti secara ilmiah (Thomas \& George, 2015). Menurut Dai (1998), penjerapan oleh arang aktif terjadi melalui mekanisme pembentukan gaya elektrostatik (tarik-menarik) sebagai akibat dari perbedaan muatan antara permukaan karbon pada arang aktif dengan senyawa yang akan dijerap dalam larutan sampel. Rasio kemurnian C-fikosianin terbesar yang diperoleh pada penelitian ini dan didapatkan dari penggunaan arang aktif konsentrasi $5,0 \mathrm{~g} / \mathrm{L}(2,408 \pm$ 0,171 ) menunjukkan peningkatan sebesar 2,68 kali lipat bila dibandingkan dengan kemurnian awalnya atau kemurnian ekstrak kasar C-fikosianin (0,900 \0,067).

Penelitian ini menambah daftar panjang kemampuan arang aktif dalam menjerap berbagai senyawa pengotor dalam suatu larutan campuran. Namun, jika arang aktif digunakan dalam konsentrasi yang cukup tinggi, maka penjerapan pigmen Cfikosianin bisa saja terjadi. Hal tersebut dapat terlihat pada Tabel 2, semakin tinggi konsentrasi arang aktif yang digunakan maka semakin rendah rasio kemurnian C-fikosianin yang didapat. Oleh karena itu, penggunaan arang aktif sebagai penjerap dalam proses pemurnian C-fikosianin perlu dioptimasi terlebih dahulu, baik itu dari sisi konsentrasinya maupun dari sisi sumber arang aktifnya. Materi yang digunakan

Tabel 2. Pengaruh arang aktif pada pemurnian pigmen C-fikosianin

Table 2. The effect of activated carbon in the purity of $C$-phycocyanin pigment

\begin{tabular}{lcc}
\hline \multicolumn{1}{c}{$\begin{array}{c}\text { Perlakuan/ } \\
\text { Treatment }\end{array}$} & $\begin{array}{c}\text { Rasio Kemurnian/ } \\
\text { Purity Ratio } \\
\left(\mathbf{A}_{\mathbf{6 2 0}} / \mathbf{A}_{\mathbf{2 8 0}}\right)\end{array}$ & $\begin{array}{c}\text { Persentase Peningkatan/ } \\
\text { Increasing Percentage } \\
(\%)\end{array}$ \\
\hline Kitosan/Chitosan $0.3 \mathrm{~g} / \mathrm{L}$ & $1.42 \pm 0.04$ & 57.5 \\
Arang Aktif/Activated carbon $2.5 \mathrm{~g} / \mathrm{L}$ & $2.34 \pm 0.01$ & 159.4 \\
Arang Aktif/Activated carbon $5.0 \mathrm{~g} / \mathrm{L}$ & $2.41 \pm 0.18$ & 167.5 \\
Arang Aktif/Activated carbon $7.5 \mathrm{~g} / \mathrm{L}$ & $1.98 \pm 0.12$ & 120.0 \\
Arang Aktif/Activated carbon $10.0 \mathrm{~g} / \mathrm{L}$ & $1.57 \pm 0.22$ & 74.6 \\
\hline
\end{tabular}


Tabel 3. Toksisitas ekstrak C-fikosianin sebelum dan setelah pemurnian Table 3. The toxicity of $C$-phycocyanin extract before and after purification

\begin{tabular}{lcccc}
\hline \multicolumn{1}{c}{$\begin{array}{c}\text { Sampel/ } \\
\text { Sample }\end{array}$} & $\begin{array}{c}\text { Konsentrasi/ } \\
\text { Concentration } \\
(\mathbf{p p m})\end{array}$ & $\begin{array}{c}\text { \%-Mortalitas/ } \\
\text { \%-Mortality }\end{array}$ & LC50 (ppm) & $\begin{array}{c}\text { Keterangan/ } \\
\text { Information }\end{array}$ \\
\hline Sebelum Perlakuan/ & 1000 & 100.0 & 15.75 & Toksik \\
Before Treatment & 100 & 53.3 & 60.0 & \multirow{2}{*}{ Toksik } \\
\hline Setelah Perlakuan Kitosan & 10 & 100.0 & \\
dan Arang Aktif/After & 1000 & 77.0 & & \\
$\begin{array}{l}\text { Treatment using Chitosan } \\
\text { and Activated Carbon }\end{array}$ & 100 & 57.0 & & \\
\hline Kontrol/Control & 10 & 20.0 & & \\
\hline
\end{tabular}

sebagai sumber perolehan arang aktif ikut mempengaruhi karakteristik dari arang aktif yang dihasilkan (Thomas \& George, 2015). Berdasarkan hasil yang diperoleh dapat terlihat bahwa penambahan kitosan dan arang aktif berhasil meningkatkan rasio kemurnian C-fikosianin pada ekstrak kasar sianobakteria laut Jaaginema sp. BTM-11. Kapasitas pengikatan kitosan dan kapasitas penjerapan arang aktif merupakan kombinasi dua mekanisme yang tepat dalam meningkatkan rasio kemurnian pigmen Cfikosianin Jaaginema sp. BTM-11.

Uji toksisitas dengan menggunakan metode BSLT (Tabel 3) menunjukkan bahwa ekstrak pigmen Cfikosianin dari sianobakteria laut Jaaginema sp. BTM11 memiliki tingkat toksisitas yang tinggi. Uji BSLT digunakan sebagai uji pendahuluan (praskrining) untuk mengetahui tingkat toksisitas suatu senyawa atau campuran senyawa yang masuk ke dalam tubuh makhluk hidup (Sukandar, Hermanto, \& Lestari, 2017). Suatu ekstrak dianggap toksik apabila memiliki nilai LC $_{50}$ kurang dari 1000 ppm, sedangkan untuk senyawa murni dikatakan toksik apabila memiliki LC $_{50}$ kurang dari 200 ppm (Meyer et al., 1982). Nilai LC $_{50}$ dari ekstrak pigmen $\mathrm{C}$-fikosianin sebelum mendapat perlakuan kitosan dan arang aktif bahkan sudah cukup tinggi dan tergolong sangat toksik $\left(\mathrm{LC}_{50}=15,75 \mathrm{ppm}\right)$. Peningkatan kemurnian $\mathrm{C}$-fikosianin dengan menggunakan kitosan dan arang aktif juga semakin meningkatkan toksisitas dari ekstrak pigmen Jaaginema sp. BTM-11 ( $\left.\mathrm{LC}_{50}=12,06 \mathrm{ppm}\right)$. Sementara itu, C-fikosianin sendiri merupakan suatu senyawa yang diketahui memiliki toksisitas yang rendah (Jiang et al., 2017). Hal tersebut menunjukkan bahwa komponen toksik dari sianobakteria laut Jaaginema sp. BTM-11 masih terkandung dalam fraksi pigmen
C-fikosianin. Fraksi C-fikosianin dengan nilai $\mathrm{LC}_{50}$ sebesar 12,06 ppm dikategorikan sebagai fraksi yang memiliki aktivitas sitotoksik yang kuat oleh Meyer et al. (1982).

Hasil penelitian Mustopa et al. (2016) menunjukkan bahwa senyawa yang bertanggung jawab atas aktivitas antivirus dan antibakteri dari sianobakteria laut Jaaginema sp. BTM-11 merupakan senyawa lektin. Lektin merupakan golongan senyawa yang termasuk ke dalam golongan protein yang umumnya terdapat dalam bentuk terikat dengan senyawa karbohidrat spesifik yang berperan sebagai senyawa mediator dalam proses transfer informasi pada suatu sistem biologis (Nilsson, 2007). Di sisi lain, Pandey et al. (2009) menyatakan bahwa senyawa lektin dapat berinteraksi dengan senyawa C-fikosianin melalui suatu ikatan lemah. Hal tersebut mengindikasikan adanya kemungkinan bahwa pada fraksi pigmen Cfikosianin Jaaginema sp. BTM-11 juga terkandung senyawa lektin, sehingga fraksi pigmen C-fikosianin tersebut patut diduga memiliki aktivitas antivirus dan antibakteri. Pigmen C-fikosianin dan senyawa lektin keduanya merupakan senyawa protein alga (Liang \& Wen, 2014).

\section{KESIMPULAN}

Penggunaan kitosan dan arang aktif dalam proses pemurnian pigmen $\mathrm{C}$-fikosianin dari sianobakteria laut Jaaginema sp. BTM-11 merupakan metode yang efektif, karena secara signifikan dapat meningkatkan rasio kemurnian pigmen $\mathrm{C}$-fikosianin hingga mencapai 2,68 kali lipat kemurnian awalnya. Peningkatan kemurnian pigmen $\mathrm{C}$-fikosianin diikuti dengan peningkatan toksisitasnya pada uji BSLT. Fraksi 
pigmen C-fikosianin yang telah melewati proses pemurnian dengan kitosan dan arang aktif lebih toksik dibandingkan dengan fraksi C-fikosianin yang belum dimurnikan. Hal itu ditandai dengan meningkatnya nilai $\mathrm{LC}_{50}$ dari 15,75 ppm menjadi 12,06 ppm. Pembuktian aktivitas antivirus dan antibakteri dari fraksi pigmen C-fikosianin Jaaginema sp. BTM-11 perlu dilakukan pada penelitian lebih lanjut.

\section{DAFTAR PUSTAKA}

Becker, E. (1994). Microalgae: Biotechnology and Microbiology (1st Editio). Cambridge University Press.

Bhaskar, S. U., Gopalaswamy, G., \& Raghu, R. (2005). A simple method for efficient extraction and purification of C-phycocyanin from Spirulina platensis Geitler. Indian Journal of Experimental Biology, 43(March), 277-279.

Cisneros, M., \& Rito-palomares, M. (2014). A simplified strategy for the release and primary recovery of cPhycocyanin produced by Spirulina maxima. Chemical and Biochemical Engineering Quarterly, 18(4), 385-390.

Dai, M. (1998). Mechanism of adsorption for dyes on activated carbon. Journal of Colloid and Interface Science, 198(1), 6-10.

Fekrat, F., Nami, B., Ghanavati, H., Ghaffari, A., \& Shahbazi, M. (2018). Optimization of chitosan / activated charcoal-based purification of Arthrospira platensis phycocyanin using response surface methodology. Journal of Applied Phycology, 1-11. https://doi.org/ https://doi.org/10.1007/s10811-018-1626-8

Fernández-rojas, B., Hernández-juárez, J., \& Pedrazachaverri, J. (2014). Nutraceutical properties of phycocyanin. Journal of Functional Foods, 11, 375392. https://doi.org/10.1016/j.jff.2014.10.011

Gantar, M., Simovic, D., Djilas, S., Gonzalez, W. W., \& Miksovska, J. (2012). Isolation, characterization and antioxidative activity of C-Phycocyanin from Limnothrix sp. strain 37-2-1. Journal of Biotechnology, 159(12), 21-26. https://doi.org/10.1016/ j.jbiotec.2012.02.004. Isolation

Gupta, A., \& Sainis, J. K. (2010). Isolation of Cphycocyanin from Synechococcus sp., (Anacystis nidulans BD1). Journal of Applied Phycology, 22(August 2016), 231-233. https://doi.org/10.1007/ s10811-009-9449-2

Horvath, H., Attila, K. W., Riddick, C., \& Presing, M. (2013). Extraction methods for phycocyanin determination in freshwater filamentous cyanobacteria and their application in a shallow lake. European Journal of Phycology, 48(3), 278-286. https://doi.org/10.1080/ 09670262.2013 .821525

Ilter, I., Akyil, S., Demirel, Z., Koç, M., Conk-dalay, M., \& Kaymak-Ertekin, F. (2018). Optimization of phycocyanin extraction from Spirulina platensis using different techniques. Journal of Food Composition and Analysis, 70(April), 78-88. https://doi.org/ 10.1016/j.jfca.2018.04.007
Jiang, L., Wang, Y., Yin, Q., Liu, G., Liu, H., Huang, Y., \& Li, B. (2017). Phycocyanin/ : A potential drug for cancer treatment. Journal of Cancer, 8, 3416-3429. https:// doi.org/10.7150/jca.21058

Liang, Y., \& Wen, Z. (2014). Bio-based nutraceuticals from biorefining. In K. Waldron (Ed.), Advances in Biorefineries: Biomass and Waste Supply Chain Exploitation (pp. 596-615). Elsevier Science \& Technology.

Maccoll, R. (1998). Cyanobacterial phycobilisomes. Journal of Structural Biology, 124, 311-334.

Martelli, G., Folli, C., Visai, L., Daglia, M., \& Ferrari, D. (2014). Thermal stability improvement of blue colorant C-Phycocyanin from Spirulina platensis for food industry applications. Process Biochemistry, 49, 154159. https://doi.org/10.1016/j.procbio.2013.10.008

Meyer, B. N., Ferrigni, N. R., Putnam, J. E., Jacobson, L. B., Nichols, D. E., \& McLaughlin, J. L. (1982). Brine shrimp: a convenient general bioassay for active plant constituents. Planta Medica, 45, 31-34.

Mustopa, A. Z., Nurilmala, M., \& Susilaningsih, D. (2016). Molecular identification of microalgae BTM 11 and its lectin isolation, characterization and inhibition activity. Annales Bogorienses, 20(December), 37-44.

Nilsson, C. L. (2007). Lectins: Analytical tools from nature. In C. L. Nilsson (Ed.), Lectins (pp. 1-13). Elsevier B.V. https://doi.org/https://doi.org/10.1016/B978-0-44453077-6.X5000-5

Pandey, G., Fatma, T., \& Komath, S. S. (2009). Specific interaction of the legume lectins, concanavalin $A$ and peanut agglutinin, with Phycocyanin. Photochemistry and Photobiology, 85, 1126-1133. https://doi.org/ 10.1111/j.1751-1097.2009.00571.x

Patil, G., Chethana, S., Sridevi, A. S., \& Raghavarao, K. S. M. S. (2006). Method to obtain C-phycocyanin of high purity. Journal of Chromatography, 1127, 76-81. https:/ /doi.org/10.1016/j.chroma.2006.05.073

Praharyawan, S., Rahman, D. Y., \& Susilaningsih, D. (2016). Characterization of lipid productivity and fatty acid profile of three fast-growing microalgae isolated from Bengkulu for possible use in health application. Journal of Tropical Life Science, 6(2), 79-85. https:// doi.org/10.11594/jtls.06.02.03

Rastogi, R. P., \& Sinha, R. P. (2009). Biotechnological and industrial significance of cyanobacterial secondary metabolites. Biotechnology Advances, 27(4), 521-539. https://doi.org/10.1016/ j.biotechadv.2009.04.009

Santiago-santos, M. C., Ponce-noyola, T., Olvera-ram, R., Ortega-lópez, J., \& Cañizares-villanueva, R. O. (2004). Extraction and purification of phycocyanin from Calothrix sp . Process Biochemistry, 39, 2047-2052. https://doi.org/10.1016/j.procbio.2003.10.007

Sekar, S., \& Chandramohan, M. (2008). Phycobiliproteins as a commodity: Trends in applied research, patents and commercialization. Journal of Applied Phycology, 20, 113-136. https://doi.org/10.1007/s10811-0079188-1

Silveira, S. T., Quines, L. K. de M., Burkert, C. A. V., \& Kalil, S. J. (2008). Separation of phycocyanin from Spirulina 
platensis using ion exchange chromatography. Bioprocess and Biosystem Engineering, 31, 477-482. https://doi.org/10.1007/s00449-007-0185-1

Sinha, R. P. \& Häder D. (1996). Photobiology and ecophysiology of rice field cyanobacteria. Photochemistry and Photobiology, 64(December), 887-896. 1097.1996.tb01852.x

Sukandar, D., Hermanto, S., \& Lestari, E. (2017). Uji toksisitas ekstrak daun Pandan Wangi (Pandanus amaryllifolius Roxb .) dengan metode Brine Shrimp Lethality Test ( BSLT ). Jurnal Kimia Valensi, 1(2), 63-70. https://doi.org/10.15408/jkv.v1i2.217

Thomas, B. N., \& George, S. C. (2015). Production of activated carbon from natural sources. Trends in Green Chemistry, 1, 1-5.

Vold, I. M. N., Varum, K. M., Guibal, E., \& Smidsrød, O. (2003). Binding of ions to chitosan-selectivity studies. Carbohydrate Polymers, 54, 471-477. https://doi.org/ 10.1016/j.carbpol.2003.07.001 